\title{
TOTAL CONTENT AND AVAILABILITY OF MICRONUTRIENTS IN SOILS AND LIVESTOCK MANURE
}

\author{
Contenido total y disponibilidad de micronutrientes en suelos y excretas bovinas
}

\author{
María Laura RAMOS*, Carlos Hernán MOSCUZZA and Alicia FERNÁNDEZ CIRELLI
}

\author{
Instituto de Investigaciones en Producción Animal (INPA-UBA-CONICET) y Centro de Estudios Transdiscipli- \\ narios del Agua (CETA-UBA), Facultad de Ciencias Veterinarias, Universidad de Buenos Aires, Av. Chorroarín \\ 280 (C1427CWO), Buenos Aires, Argentina \\ *Corresponding author: mramos@fvet.uba.ar
}

(Received May 2018; accepted May 2019)

Key words: trace metals, cattle manure, sequential extraction, organic fertilization

\begin{abstract}
The use of feedlot cattle manure appears as an important source of certain trace metals in soils that can be mobilized by water modifying the surface and groundwater quality. The current study is focused on assessing the availability of copper $(\mathrm{Cu})$, zinc $(\mathrm{Zn})$, cobalt $(\mathrm{Co})$ and molybdenum (Mo) in manure from confined beef cattle systems and different soils of the Chaco-pampean plain, using a sequential extraction scheme. Soils and bovine manure coming from intensive (IS) and extensive (ES) beef cattle systems were collected. Total contents of $\mathrm{Cu}, \mathrm{Zn}, \mathrm{Co}$ and $\mathrm{Mo}$ were determined after microwave assisted acid digestion. Availability was evaluated through sequential extraction, including water-soluble and exchangeable fraction $(\mathrm{EXCH})$, organic matter bound fraction $(\mathrm{OM})$, inorganic precipitated fraction (INOR), and residual fraction (RES). Total $\mathrm{Cu}$ and $\mathrm{Zn}$ contents found in manure coming from IS were higher than the concentration of the aforementioned trace elements determined in all soils and manure analyzed from ES. EXCH-Cu only appears in IS cattle manure samples, while $\mathrm{EXCH}-\mathrm{Zn}$ found in IS manure samples were higher than the soils samples analyzed. The higher levels of total and availability forms of $\mathrm{Cu}$ and $\mathrm{Zn}$ determined in IS manure compared to soils samples, require considering when this organic amendment is applied as fertilizer. These results indicate that the reuse of intensive cattle manure as fertilizer in agricultural areas could provide available forms of metals in soils and could contribute to reduce the environmental impact caused by the accumulation of excreta in pen soils during long periods in farms.
\end{abstract}

Palabras clave: elementos traza, estiércol bovino, extracción secuencial, fertilización orgánica

\section{RESUMEN}

El uso de excretas provenientes de sistemas intensivos de engorde bovino aparece como una fuente importante de ciertos metales traza en suelos, los cuales pueden ser movilizados por escorrentía y lixiviado, modificando la calidad de cursos de agua superficial y subterránea. Este trabajo propone evaluar la disponibilidad de cobre $(\mathrm{Cu})$, zinc $(\mathrm{Zn})$, cobalto (Co) y molibdeno (Mo) en excretas provenientes de sistemas intensivos de engorde bovino y en diferentes suelos de la llanura Chaco-pampeana, utilizando un 
procedimiento de extracción secuencial. Se recolectaron muestras de suelos y excretas provenientes de sistemas intensivos (SI) y extensivos (SE) de producción de ganado vacuno. Los contenidos totales de $\mathrm{Cu}, \mathrm{Zn}$, Co y Mo se determinaron mediante digestión ácida asistida por microondas. La disponibilidad fue evaluada mediante un esquema de extracción secuencial que incluyó una fracción soluble en agua e intercambiable (INT), una fracción unida a materia orgánica (MO), una fracción inorgánica (INOR) y una fracción residual (RES). Los resultados obtenidos mostraron mayores contenidos totales y de la fracción intercambiable de $\mathrm{Cu}$ y $\mathrm{Zn}$ en excretas provenientes de SI respecto de las muestras de suelos y excretas provenientes de SE. Estos resultados indicarían que el uso de las excretas de sistemas intensivos de engorde bovino incrementaría las formas más disponibles de metales en suelos, de modo tal que su empleo como enmiendas orgánicas puede contribuir a reducir el impacto ambiental que origina su acumulación en suelos de corrales.

\section{INTRODUCTION}

Population growth and global demand for agricultural products have promoted an important increase in livestock production (FAO 2002). In Argentina, traditional beef cattle systems, mainly grazing or extensive were modified to intensive production units, where animals are fed with diets based on concentrated foods. For instance, 1.47 million heads of cattle were fattened in beef cattle intensive systems in 2017 (MAGyP 2017).

Concentrated foods contain a high nutrient load to achieve efficient production rates, but in general beef cattle retain less than $20 \%$ of the consumed nutrients (Hou et al. 2016). The excreta levels daily eliminated by a bovine are around 5 to $6 \%$ of their body weight. For example, a steer of $400 \mathrm{~kg}$ live weight generate between 20-25 kg of manure per day. Considering an $80-85 \%$ moisture, an average of $3 \mathrm{~kg}$ of solid residue is daily produced per animal (Steinfeld et al. 2006).

The production and storage of these wastes are responsible for most environmental problems associated with intensive beef cattle production systems (De Vries et al. 2015). Major forms of pollution associated with manure management in intensive livestock production include eutrophication of surface water, leaching of nitrates and pathogens, nutrients and trace metals accumulation in soils, release of ammonia, methane and other gases (FAO 2005).

Most of the environmental problems associated with land application of manure have centered on surface and/or groundwater pollution with nitrogen or phosphorus. However, the high levels of trace elements observed in manure of confined beef cattle condition a potential danger of soil pollution (Sungur et al. 2016). Trace metals accumulation in soil through manure application may cause phytotoxic- ity and zootoxicity problems; or may leave soils by leaching surface-water runoff, causing water and sediment contamination. In previous studies in our lab, it was determined that trace elements, mainly $\mathrm{Cu}$ and $\mathrm{Zn}$, are eliminated in beef cattle manure in high levels and repeated land application resulted in elevated concentrations of these metals in soils. Metal accumulation appeared to be directly proportional to the age of emplacement of the establishment (Moscuzza and Fernández-Cirelli 2009).

In order to mitigate the environmental effect, cattle manure has been used in biogas production or organic fertilization. Livestock manure has been traditionally used as an organic fertilizer in farmlands, employed to improve soil quality and recover phosphorus, carbon, and nitrogen, essential nutrients for plants growth (Zhao et al. 2014). It has been reported that the addition of animal manure or compost increases organic matter content and improves the soil aggregates stability, porosity, water retention and infiltration capacity (Sager 2007).

In the Chaco-pampean plain, a wide agricultural region located in the center of Argentina where most intensive beef cattle production units are located, many soils present low levels of micronutrients such as $\mathrm{Cu}$ and $\mathrm{Zn}$, and deficiencies have been reported in grazing cattle (Lavado et al. 2004, Lavado 2006). Therefore, the use of manure from intensive beef cattle production systems as a source of organic fertilizer could represent an environmentally friendly way of disposing these organic wastes and supplement soils and forages destined to grazing cattle in an area naturally deficient in these micronutrients.

Several factors including metals adsorption in soils, metals distribution between the different geochemical fractions and availability, should be considered when manure is applied as fertilizer in crop soils (Torri and Lavado 2008, Achiba et al. 2010). 
Within this context, it will be of interest to predict potential changes of the mobility and availability of trace elements arising from feedlot manure application and the inorganic compositions of the target soils from various organic fertilizers. Therefore, in the present study the availability of copper, zinc, cobalt and molybdenum will be studied in manure from confined beef cattle systems and different soils samples from the Chaco-pampean plain, by using a sequential extraction scheme.

\section{MATERIALS AND METHODS}

Soil samples from different regions of the Chacopampean plain in Argentina were collected. Five sampling sites were selected taking into account the differences in edaphoclimatic conditions between agro-ecological zones. These sites were located in different departments of the Buenos Aires province (Fig. 1):

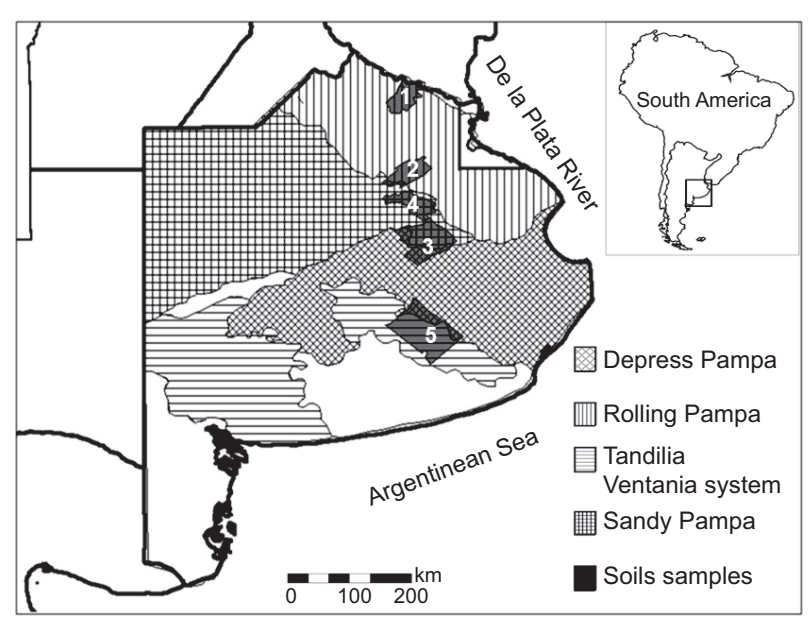

Fig. 1. Different agro-ecological zones of the Buenos Aires province and soil samples, adapted from Secretaría de Agricultura, Ganadería, Pesca y Alimentos (1995)

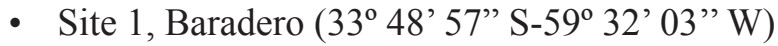

- Site 2, Navarro (34 $\left.58^{\circ} 19^{\prime \prime} \mathrm{S}-59^{\circ} 08^{\prime} 22^{\prime \prime} \mathrm{W}\right)$

- Site 3, Las Flores (35 51' 54" S-58 $54^{\circ}$ ' 43" W)

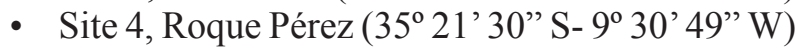

- Site 5, Tandil ( $37^{\circ} 19^{\prime} 55^{\prime \prime}$ S-59 $09^{\circ}$ ' 25" W)

Baradero is located in the "rolling Pampa". Las Flores and Roque Pérez departments are part of the northwest of Buenos Aires province, denominated "sandy Pampa". The Navarro department is in the north border of the "depressed Pampa". The transition zone with the rolling Pampa and Tandil belongs to an area denominated "Tandilia system", a zone of hills. Soil samples (0-10 cm depth) were obtained by an auger blade in uniform environments with minimal anthropic disturbance due to tillage (sampling land surface: 2-3 ha). About 20 aliquots were collected following a zig-zag pattern, ensuring equidistance between sampling points. Samples were mixed to obtain a final sample of $1 \mathrm{~kg}$, stored in polyethylene double bags and labeled. Samples were air dried and sieved $(2 \mathrm{~mm})$ before analysis. Characteristics of Buenos Aires province soils, provided by the Soil Institute of INTA, were used to characterize the sampled environments (INTA 1988).

Also, homogeneous samples of bovine manure from three beef cattle intensive systems (IS) and from a cattle extensive system (ES) was collected. In each system, 30 manure subsamples $(0.5 \mathrm{~kg})$ were obtained with a steel plain shovel avoiding soil incorporation. Subsamples were mixed and the final sample $(1 \mathrm{~kg})$ was preserved at $4{ }^{\circ} \mathrm{C}$ in a double plastic bag, air dried and sieved $(2 \mathrm{~mm})$ before analysis.

Soil samples were characterized by measuring extractable phosphorus (Bray-Kurtz method), $\mathrm{pH}$ (1:2.5 soil water ratio), organic carbon (OC; WalkleyBlack method), and total Kjeldahl nitrogen (TKN; Microkjeldahl method). Moreover, electrical conductivity (EC), cation content $\left(\mathrm{Ca}^{2+}, \mathrm{Mg}^{2+}, \mathrm{Na}^{+}\right.$and $\mathrm{K}^{+}$ by the atomic absorption method), cation exchange capacity (CEC; steam-distillation method) and clay content (Bouyoucous method) were determined. Detailed description of these methods can be found in Sparks (1996). All manure samples were characterized using similar methods and techniques.

The total content of $\mathrm{Cu}, \mathrm{Zn}, \mathrm{Co}$ and Mo was determined in soils and manure samples by microwave assisted acid digestion (Microwave 3000, Anton Paar, Austria) using the method 3051A (USEPA 1996). Four fractions of these elements were obtained from all samples by the sequential extraction procedure of McGrath and Cegarra (1992): water-soluble and exchangeable fraction $(\mathrm{EXCH})$, organic matter bound fraction $(\mathrm{OM})$, inorganic precipitate fraction (INORG) and residual fraction (RES). Soil and manure samples $(3 \mathrm{~g})$ were placed into a $50 \mathrm{~mL}$ centrifuge tube; $30 \mathrm{ml}$ of $\mathrm{CaCl}_{2} 0.1 \mathrm{M}(\mathrm{EXCH}), \mathrm{NaOH} 0.5$ $\mathrm{M}(\mathrm{OM}), \mathrm{Na}_{2}$ EDTA $0.05 \mathrm{M}$ (INOR) reagents were sequentially added and each one shaken for $16 \mathrm{~h}$. The residual fraction (RES) was calculated as the difference between total content of the metal previously determined and the addition of the extracted fractions $(\mathrm{EXCH}+\mathrm{OM}+\mathrm{INOR})$. At the end of each 
extraction, soil suspensions were centrifuged at 3600 rpm for 45 min and filtered through Wathman filter paper grade 42 . Because $\mathrm{NaOH}$ and $\mathrm{Na}_{2}$ EDTA reagents also extracted organic matter, the supernatant was digested in aqua regia $\left(\mathrm{HNO}_{3} / \mathrm{HCl}, 1: 3\right)$ prior to metal quantification.

Contents of $\mathrm{Cu}, \mathrm{Zn}, \mathrm{Co}$ and Mo were analyzed in all extracts by atomic emission spectrometry (ICP-OES Optima 3000 DV, Perkin Elmer) using an external calibration with quality control standard 21 (atomic spectroscopy standard, Perkin Elmer Pure $100 \mathrm{mg} / \mathrm{L})$.

\section{RESULTS AND DISCUSSION}

\section{Physical and chemical characteristics of soil and manure samples}

According to geo-referenced site information of physical and chemical characteristics, soil sample of site 1 correlated with Atucha (At) series (Soil Chart INTA, number 3360-35, Baradero). Taxonomically, these soils are classified as Abruptic Argiudolls and Typic Argiudolls (SSS 2014). Soil samples corresponding to site 2 correlated with Navarro $(\mathrm{Na})$ series (Soil Chart INTA, number 3560-17, Tomás Jofré) and are classified as Argiaquic Argialbolls (SSS 2014). Soil samples corresponding to site 3 corresponded to Tronconi (Tri) series (Soil Chart INTA, number 3560-35, Juan Blaquier) and are classified as Natric Duraquolls. Soil samples corresponding to site 4 matched with Pueblitos series (Pu) (Soil Chart INTA, number 3560-29, Roque Pérez). Taxonomically, these soils are classified as Typic Argiaquolls and Argiaquic Argialbolls (SSS 2014). Soil samples corresponding to site 5 resembled Tandil (Ta) series (Soil Chart INTA, number 3760-23 and are classified as Typic Argiudolls).

The characteristics of the soil samples from the selected departments are shown in table I. Results are consistent with the typical characteristics of soils in these agro-ecological areas (Salazar and Moscatelli 1989). Additionally, a north-south gradient of clay and sand content was observed. Soils from north of the Buenos Aires province (Baradero and Navarro) presented higher levels of clay in comparison with the southern departments. In case of sand, south soils showed the highest levels (Las Flores and Roque Pérez). These obtained gradients are typical in soils from the Pampean Region. All soils samples were slightly acidic except the sample from Roque Pérez and showed low values of EC. Samples from Las Flores, Roque Pérez and Tandil had the highest levels of OC and TKN. Soil from Navarro presented the highest phosphorus content. Also, the variability observed in CEC values is related to the size and type of clay, and OC \% of each soil sample.

TABLE I. PHYSICAL AND CHEMICAL CHARACTERISTICS OF THE SAMPLED SOILS (0-10 CM)

\begin{tabular}{lccccc}
\hline Locality & Baradero & Navarro & Las Flores & Roque Pérez & Tandil \\
\hline Clay $(\%)$ & 27.5 & 20.0 & 15.0 & 15.0 & 15.0 \\
Silt $(\%)$ & 53.5 & 56.2 & 43.9 & 42.1 & 51.7 \\
Sand $(\%)$ & 19.0 & 23.8 & 38.1 & 42.9 & 33.3 \\
Soil texture & Clay silt & Silt & Silt & Silt & Silt \\
$\mathrm{pH}^{\mathrm{a}}$ & 6.9 & 6.4 & 6.9 & 8.1 & 6.5 \\
$\mathrm{EC}(\mathrm{dS} / \mathrm{m})$ & 0.2 & 0.3 & 0.1 & 0.3 & 0.1 \\
$\mathrm{Ext} . \mathrm{P}(\mathrm{mg} / \mathrm{kg})$ & 4.3 & 54.2 & 35.7 & 5.1 & 33.3 \\
$\mathrm{OC}(\%)$ & 1.3 & 1.8 & 2.6 & 2.1 & 2.8 \\
$\mathrm{TNK}(\%)$ & 0.1 & 0.2 & 0.2 & 0.2 & 0.2 \\
$\mathrm{Ca}(\mathrm{cmol} / \mathrm{Kg})$ & 7.6 & 13.6 & 14.6 & 11.9 & 16.9 \\
$\mathrm{Mg}\left(\mathrm{cmol}_{\mathrm{c}} / \mathrm{Kg}\right)$ & 1.4 & 1.9 & 2.0 & 1.4 & 2.2 \\
$\mathrm{Na}\left(\mathrm{cmol}_{\mathrm{c}} / \mathrm{Kg}\right)$ & 0.4 & 0.3 & 0.3 & 0.3 & 0.2 \\
$\mathrm{~K}(\mathrm{cmol} / \mathrm{Kg})$ & 0.9 & 1.5 & 1.4 & 1.0 & 1.5 \\
$\mathrm{CEC}\left(\mathrm{cmol}_{\mathrm{c}} / \mathrm{Kg}\right)$ & 13.0 & 21.0 & 23.6 & 15.2 & 26.0 \\
\hline
\end{tabular}

${ }^{\mathrm{a}} \mathrm{pH}$ measured potenciometrically in a 1:2.5 soil water ratio, ECV: electrical conductivity measured, Ext. P: extractable phosphorus by the Bray-Kurtz method, OC: organic carbon measured by the Walkley-Black method, TKN: total Kjeldahl nitrogen measured by the Microkjeldahl method, cation content $(\mathrm{Ca}, \mathrm{Mg}, \mathrm{Na}, \mathrm{K})$ measured by the atomic absorption method, CEC: cation exchange capacity measured by the steam-distillation Method. Detailed description of these methods can be found in Sparks (1996) 
Manure samples from IS showed higher levels of total organic carbon (22.5-31.6\%), total Kjeldahl nitrogen (1.6- .8\%), and extractable phosphorus $(139.7-144 \mathrm{mg} / \mathrm{kg})$ in comparison to soil samples. In contrast with soil samples values, manure showed a slightly alkaline $\mathrm{pH}$ and higher EC (Table II).

TABLE II. PHYSICAL AND CHEMICAL CHARACTERISTICS FROM CATTLE MANURE SAMPLES COMING FROM INTENSIVE PRODUCTION SYSTEMS (IS)

\begin{tabular}{lrrr}
\hline & IS-1 & IS-2 & IS-3 \\
\hline $\mathrm{pH}^{\mathrm{a}}$ & 7.8 & 7.6 & 8.7 \\
$\mathrm{ECV}(\mathrm{dS} / \mathrm{m})$ & 0.6 & 2.2 & 1.4 \\
Ext. P $(\mathrm{mg} / \mathrm{kg})$ & 139.6 & 143.1 & 143.9 \\
OC $(\%)$ & 29.6 & 22.5 & 31.6 \\
TKN $(\%)$ & 1.6 & 1.6 & 1.8 \\
\hline
\end{tabular}

${ }^{\mathrm{a}} \mathrm{pH}$ measured potenciometrically in a 1:2.5 soil water ratio, ECV: electrical conductivity measured, Ext. P: extractable phosphorus by the Bray-Kurtz method, OC: organic carbon measured by the Walkley-Black method, TKN: total Kjeldahl nitrogen measured by the Microkjeldahl method. Detailed description of these methods can be found in Sparks (1996)

For NTK \%, OC \%, $\mathrm{pH}$ and $\mathrm{EC}(\mathrm{dS} / \mathrm{m})$ values, results obtained in the present work were in agreement with nutrient composition of beef cattle manure found in published researches. Total Kjeldahl nitrogen ranged 0.93-2.43\%; total organic carbon 5-16\%, $\mathrm{pH} 7.5-8.6$ and EC 1.76-9.06 dS/m. However, extractable phosphorus content in $\mathrm{mg} / \mathrm{kg}$ was lower than values reported in bibliography $(720-3100 \mathrm{mg} / \mathrm{kg}$ ) (Eghball and Power 1994, Hernández et al. 2002, Irshad et al. 2013, Magrí and Teira-Esmatges 2015). Nutrient content in feedlot manure will differ considerably depending on the type of animal, its food ration and the method of collection and storage. Feedlot manure was a traditional source of nutrients (primarily NTK and P) and organic matter. Land application improves the overall soil quality and reduces soil and water losses. Total salt concentrations can be used to estimate EC. Manure may contain high levels of soluble salts (Reynolds et al. 2002). Calcium carbonate $\left(\mathrm{CaCO}_{3}\right)$ is commonly added to cattle diets as a source of calcium, and the recommended level is $7 \mathrm{~g} / \mathrm{kg}$ of ration (Klemesrud et al. 1998). Much of the $\mathrm{CaCO}_{3}$ is excreted and the $\mathrm{pH}$ of manure can be increased (become more basic) as a result (Eghball 1999). These facts could explain the higher EC and slightly alkaline $\mathrm{pH}$ obtained in manure samples analyzed in our work.

\section{Concentration of heavy metals in soil and manure samples}

Total concentrations of $\mathrm{Cu}, \mathrm{Zn}, \mathrm{Co}$ and $\mathrm{Mo}$ in soils are shown in table III. Levels of $\mathrm{Cu}$ ranged from 6 to $15 \mathrm{mg} / \mathrm{kg}$; and $\mathrm{Zn}$ ranged from 9 to $60 \mathrm{mg} /$ $\mathrm{kg}$. In the case of $\mathrm{Co}$ and $\mathrm{Mo}$, levels ranged from non-detectable in some soils samples to values of 6.5 and $4.1 \mathrm{mg} / \mathrm{kg}$, respectively. These contents are in accordance with the average concentrations found in pampas soils (Lavado et al. 2004), and within the range expected for uncontaminated soils $(\mathrm{Cu}: 1-50 \mathrm{mg} / \mathrm{kg}$; Zn: $1-900$ mg/kg; Mo: 0.1-40 mg/kg; Co: 2-40 mg/kg) (Adriano 2001).

Trace element contents in manure samples from intensive and extensive production systems are shown in table IV. Levels of total $\mathrm{Cu}$ and $\mathrm{Zn}$ were higher in IS manure compared to ES manure and soils, but they did not exceed the maximum limit in sediments and sludge to apply in agriculture according to Law $24.051(\mathrm{Cu}: 100 \mathrm{mg} / \mathrm{kg}$; Zn: $500 \mathrm{mg} / \mathrm{kg})$ (HWAL 1992). The total Cu content in manure reported in previous studies varied from 6.7 to $71.1 \mathrm{mg} / \mathrm{kg}$. For total $\mathrm{Zn}$, values ranged from 63 to $332.6 \mathrm{mg} / \mathrm{kg}$ (Nicholson et al. 1999, Sager 2007, Benke et al. 2008, Miller et al. 2018). The main source of trace elements is the mineral core used for livestock feed which conditions the trace element content in manure (Miller et al. 1991). Total levels of Co and Mo in manure from IS were similar or lower to those obtained in soils and ES manure. Since cattle requirements of these elements are low, the amount added to food is not significant (Bolan et al. 2003). The total content of $\mathrm{Co}$ in cattle manure is reported to be about 2.2 to $3.6 \mathrm{mg} / \mathrm{kg}$ (Bolan et al. 2004, Larney et al. 2008) and Sheppard and Sanipelli (2012) found total values of Mo of $3.91 \mathrm{mg} / \mathrm{kg}$.

These results underline the importance of excreta reuse as organic fertilizer to prevent trace elements accumulation and potential pollution. Manure addition is being recognized as a major source of metal input to soils. Several studies analyzed the long-term influence of cattle manure application in total and available concentration of metals in soil. An increase in total $\mathrm{Cu}$ and $\mathrm{Zn}$ content in manure-amended soils compared to unamended soils after repeated application of manures was observed, and the effect was noticeable in soils up to $0-15-30 \mathrm{~cm}$ depth (control soil: 20.6 and $17.3 \mathrm{mg} / \mathrm{kg} \mathrm{Cu}$, manure irrigated soil: $34.0-22.7 \mathrm{mg} / \mathrm{kg} \mathrm{Cu}$, respectively; total $\mathrm{Zn}$ increased from $72.2 \mathrm{mg} / \mathrm{kg}$ in the control treatment to 187.5 $\mathrm{mg} / \mathrm{kg}$ in manure amendment soils). However, no significant increase in total soil Co was detected after $25 \mathrm{yrs}$. of continuous annual manure application. This 
TABLE III. TOTAL CONTENTS AND SEQUENTIAL FRACTIONS OF Cu, Zn, Co and Mo IN SOILS (mg/kg)

\begin{tabular}{lccccc}
\hline & \multicolumn{5}{c}{ Soils } \\
\cline { 2 - 6 } & Baradero & Navarro & Las Flores & Roque Pérez & Tandil \\
\hline EXCH-Cu & nd & nd & nd & nd & nd \\
OM-Cu & $3.78(26.32 \%)$ & $0.03(0.24 \%)$ & $4.70(43.08 \%)$ & $0.91(14.7 \%)$ & $3.22(36.43 \%)$ \\
INOR-Cu & $1.72(11.98 \%)$ & $2.49(19.82 \%)$ & $1.70(15.58 \%)$ & $0.46(7.43 \%)$ & $1.20(13.57 \%)$ \\
RES-Cu & $8.86(61.70 \%)$ & $10.04(79.94 \%)$ & $4.51(41.34 \%)$ & $4.82(77.87 \%)$ & $4.42(50 \%)$ \\
Total Cu & 14.36 & 12.56 & 10.91 & 6.19 & 8.84 \\
EXCH-Zn & $11.68(27.58 \%)$ & $0.74(1.25 \%)$ & $2.01(2.11 \%)$ & $1.29(3.78 \%)$ & $0.29(0.61 \%)$ \\
OM-Zn & $0.86(2.03 \%)$ & $3.72(6.26 \%)$ & $3.91(4.11 \%)$ & $1.12(3.28 \%)$ & $3.74(7.84 \%)$ \\
INOR-Zn & $4.08(9.63 \%)$ & $10.41(17.53 \%)$ & $1.47(20.48 \%)$ & $3.56(10.42 \%)$ & $4.82(10.1 \%)$ \\
RES-Zn & $25.73(60.76 \%)$ & $44.53(74.97 \%)$ & $6.69(73.29 \%)$ & $28.18(82.52 \%)$ & $38.88(81.46 \%)$ \\
Total Zn & 42.35 & 59.40 & 9.08 & 34.15 & 47,73 \\
EXCH-Co & nd & nd & nd & nd & nd \\
OM-Co & $0.09(1.53 \%)$ & $0.38(7.29 \%)$ & $0.50(11.74 \%)$ & nd & $0.43(6.57 \%)$ \\
INOR-Co & $0.18(3.07 \%)$ & $0.33(6.33 \%)$ & $0.28(6.57 \%)$ & nd & $0.34(5.20 \%)$ \\
RES-Co & $5.60(95.40 \%)$ & $4.50(86.37 \%)$ & $3.48(81.69 \%)$ & nd & $5.77(88.23 \%)$ \\
Total Co & 5.87 & 5.21 & 4.26 & nd & 6.54 \\
EXCH-Mo & nd & nd & nd & nd & nd \\
OM-Mo & nd & $0.52(14.77 \%)$ & $0.23(7.08 \%)$ & nd & $0.49(10.4 \%)$ \\
INOR-Mo & nd & $0.49(13.92 \%)$ & $0.27(8.31 \%)$ & nd & $0.38(8.07 \%)$ \\
RES-Mo & $3.99(99.75 \%)$ & $2.51(71.31 \%)$ & $2.76(84.92 \%)$ & nd & $3.84(81.53 \%)$ \\
Total Mo & 3.99 & 3.52 & 3.25 & nd & 4.71 \\
\hline
\end{tabular}

EXCH: water-soluble and exchangeable fraction extracted with $\mathrm{CaCl}_{2} 0.1 \mathrm{M}$, nd: not detected, OM: organic matter bound fraction extracted with $\mathrm{NaOH} 0.5 \mathrm{M}$, INORG: inorganic precipitate fraction extracted with $\mathrm{Na}_{2}$ EDTA $0.05 \mathrm{M}$, RES: residual fraction calculated as total (EXCH + OM+ INOR)

In brackets: distribution of $\mathrm{Cu}, \mathrm{Zn}, \mathrm{Co}$ and $\mathrm{Mo}$ as a percentage of total content

could be attributed to the fact that the amount of Co applied over the years was probably low compared to the natural content of Co in these soils (Benke et al. 2008, Miller et al. 2018). Different results were found by Tlustoš et al. (2016), who reported that long-term farmyard manure application did not significantly change the pseudo-total and potentially mobilizable element contents. Zhao et al. (2014) investigated the risk of heavy metal contamination from cattle manure fertilization. The heavy metals analyzed $(\mathrm{Cu}, \mathrm{Zn}, \mathrm{Mn}$, $\mathrm{Fe}, \mathrm{Pb}, \mathrm{Cd}$, and $\mathrm{Cr}$ ) were gradually enriched in soils during long term application of manures and incorporation of chemical fertilizers, except for $\mathrm{Zn}$. The total $\mathrm{Zn}$ decreased to $1.8-13.8 \%$ after application of manure and total $\mathrm{Cu}$ concentrations in the soil significantly increased up to $10.6-26.7 \%$ in all manure treatments applied. These observations indicate that long term applications of manures could modified the initial status of trace metals in soils.

\section{Potential availability of trace metals in soils samples}

Results of sequential extractions in soils are shown in table III. Cu was mainly found as $\mathrm{Cu}$-RES in most of the soil samples, except for Las Flores where it was uniformly distributed between $\mathrm{Cu}-\mathrm{OM}$ and $\mathrm{Cu}-\mathrm{RES}$. Roque Pérez, Baradero and Tandil soil samples showed a similar distribution between $\mathrm{Cu}-$ $\mathrm{OM}$ and $\mathrm{Cu}-\mathrm{INOR}$, while in Navarro soil, a higher content of $\mathrm{Cu}-\mathrm{INOR}$ was found. In the five soil samples, $\mathrm{Cu}-\mathrm{EXCH}$ was below the detection limit of the analytic technique used $(\leq 0.01 \mathrm{mg} \mathrm{Cu} / \mathrm{kg})$. According to these results, the extracted soil samples did not present available forms of $\mathrm{Cu}$ but showed high percentages of the other fractions. The largest proportion of $\mathrm{Cu}$ was specifically adsorbed to organic matter and, to a lesser extent, precipitated with primary or secondary minerals or in residual fractions (Torri et al. 2011). The exchangeable fractions may indicate that the most available form for plant uptake of this metal is $\mathrm{Cu}^{2+}$. This species was below the analytical detection limit in three representative pristine soils $(<$ $0.5 \mathrm{mg} \mathrm{Cu} / \mathrm{kg}$ ) of the Pampas region. However, no $\mathrm{Cu}$ deficiencies were reported in these soils or in the rest of the Pampas region in recent years (Sainz-Rozas et al. 2003, Melgar 2006). In general, as organic matter increases, $\mathrm{Cu}$ availability decreases. Although binding with organic matter reduces fixation by soil minerals and leaching, availability of $\mathrm{Cu}$ to plants is also reduced. Krishnamurti and Naidu (2002) found a 
TABLE IV. TOTAL CONCENTRATION AND DISTRIBUTION OF Cu, Zn, Co AND Mo $(\mathrm{mg} / \mathrm{kg})$ IN MANURE COMING FROM INTENSIVE AND EXTENSIVE CONFINED LIVESTOCK SYSTEMS AMONG DIFFERENT SEQUENTIAL FRACTION

\begin{tabular}{lcccc}
\hline & ES & IS-I & IS-II & IS-III \\
\hline EXCH-Cu & $0.11(0.66 \%)$ & $1.94(3.28 \%)$ & $1.54(6.86 \%)$ & $1.67(6.67 \%)$ \\
OM-Cu & $2.19(13.19 \%)$ & $22.85(38.60 \%)$ & $11.49(51.16 \%)$ & $5.68(22.70 \%)$ \\
INOR-Cu & $5.1(30.72 \%)$ & $7.74(13.07 \%)$ & $3.17(14.11 \%)$ & $11.32(45.24 \%)$ \\
RES-Cu & $9.2(55.42 \%)$ & $26.67(45.05 \%)$ & $6.23(27.74 \%)$ & $6.35(25.38 \%)$ \\
Total Cu & 16.6 & 59.20 & 22.46 & 25.02 \\
EXCH-Zn & $1.42(2.17 \%)$ & $4.24(1.98 \%)$ & $7.07(4.35 \%)$ & $8.31(9.52 \%)$ \\
OM-Zn & $8.28(12.66 \%)$ & $54.02(25.22 \%)$ & $41.33(25.44 \%)$ & $13.34(15.28 \%)$ \\
INOR-Zn & $8.45(12.92 \%)$ & $19.32(9.02 \%)$ & $35.44(21.82 \%)$ & $22.39(25.64 \%)$ \\
RES-Zn & $47.25(72.25 \%)$ & $136.62(63.78 \%)$ & $78.6(48.39 \%)$ & $43.27(49.56 \%)$ \\
Total Zn & 65.40 & 214.20 & 162.44 & 87.31 \\
EXCH-Co & $0.07(4.79 \%)$ & $0.09(6.29 \%)$ & $0.17(11.33 \%)$ & $0.15(8.93 \%)$ \\
OM-Co & $0.1(6.85 \%)$ & $0.1(6.99 \%)$ & $0.1(6.67 \%)$ & $0.16(9.52 \%)$ \\
INOR-Co & nd & nd & $0.27(18 \%)$ & $0.1(5.95 \%)$ \\
RES-Co & $1.29(88.36 \%)$ & $1.24(86.71 \%)$ & $0.81(54 \%)$ & $0.73(43.45 \%)$ \\
Total Co & 1.46 & 1.43 & 1.50 & 1.68 \\
EXCH-Mo & $0.07(1.44 \%)$ & $0.3(20.00 \%)$ & $0.78(22.10 \%)$ & $0.7(18.92 \%)$ \\
OM-Mo & $0.45(9.24 \%)$ & $0.81(54.00 \%)$ & $0.25(7.08 \%)$ & $0.5(13.51 \%)$ \\
INOR-Mo & $1.43(29.36 \%)$ & $0.32(21.33 \%)$ & $0.48(13.60 \%)$ & $0.34(9.19 \%)$ \\
RES-Mo & $2,99(61.40 \%)$ & $0.37(24.67 \%)$ & $2.02(57.22 \%)$ & $2.16(58.38 \%)$ \\
Total Mo & 4.87 & 1.50 & 3.53 & 3.70 \\
\hline
\end{tabular}

ES: cattle manure coming from extensive production system, IS: cattle manure coming from intensive production system, $\mathrm{EXCH}$ : water-soluble and exchangeable fraction extracted with $\mathrm{CaCl}_{2}$ 0.1 M, nd: not detected, OM: organic matter bound fraction extracted with $\mathrm{NaOH} 0.5 \mathrm{M}$, INORG: inorganic precipitate fraction extracted with $\mathrm{Na}_{2}$ EDTA $0.05 \mathrm{M}$, RES: residual fraction calculated as total $(\mathrm{EXCH}+\mathrm{OM}+\mathrm{INOR})$

In brackets: distribution of $\mathrm{Cu}, \mathrm{Zn}, \mathrm{Co}$ and $\mathrm{Mo}$ as a percentage of total content

significantly correlation with fulvic complex $\mathrm{Cu}\left(\mathrm{R}^{2}\right.$ $=0.944, \mathrm{P}<0.0001)$. Fulvic complex $\mathrm{Cu}$ was found to explain $89.2 \%$ of the variation in phytoavailable $\mathrm{Cu}$. These facts indicate that $\mathrm{Cu}$ deficiencies in soils could be determined not only by the concentration in the solution phase but influenced by diffusion process from the solid-phase.

In the case of $\mathrm{Zn}$ in soil through samples, the main source was founded as Zn-RES, reaching fraction values close to $80 \%$. Moreover, the Zn-INOR fraction was higher than $\mathrm{Zn}-\mathrm{OM}$ in all soil samples. This result is typical for $\mathrm{Zn}$ found in non-contaminated soils, where it is mostly present as unreactive forms included in the crystal lattices of minerals (Shuman 1999). Unlike other metals, the Zn-EXCH fraction was observed in all soil samples. These results indicate the presence of easily available forms of $\mathrm{Zn}$ from the soil.

Co and Mo were uniformly distributed between OM and INOR fractions, but the highest proportion was found as Co-RES and Mo-RES. It is important to emphasize that the residual fraction is related to the unavailable forms of trace elements, because they are incorporated inside crystalline lattice and clays structures of soil (Soriano-Disla et al. 2010). Factors like acidic character and the increase in iron and aluminum solubility decreases Mo availability since they react with Mo making it unavailable. Co deficiency in soil is affected mainly by $\mathrm{Mn}$ and Fe oxide content in soils and the organic fraction. Transformation of Co was concomitant with the changes of $\mathrm{Mn}$, therefore, controlled by the changes of redox potential and $\mathrm{pH}$ (Han and Banin 2000, Li et al. 2004). All these factors need to be considered when Mo and Co deficiencies are evaluated in soils.

Maity et al. (2017) found a positive correlation between fine and very fine sand, silt and clay and total carbon with metal concentrations in sediments. In our work, soil samples in areas located to the northwest of Buenos Aires had a higher percentage of clay and a lower percentage of sand, in agreement with the higher total contents of $\mathrm{Cu}$ and $\mathrm{Zn}$. Likewise, factors like $\mathrm{pH}, \mathrm{CEC}$ and $\mathrm{CaCO}_{3}$ were found to have less impact in metal concentrations. Luo et al. (2012) 
determined significantly negative correlation coefficients between $\mathrm{CaCl}_{2}$ extractable metals $(\mathrm{Pb}, \mathrm{Zn})$ and soil $\mathrm{pH}$ and EC. This fact could explain the low availability determined for $\mathrm{Cu}$ y $\mathrm{Zn}$ in the soils samples (with exception of Site 1) analyzed in our work considering the $\mathrm{pH}$ values (6.4-8.0). $\mathrm{CaCl}_{2}$ mainly extracted metals in soil solution and exchangeable metals weakly adsorbed to negatively charged soil constituents. A positive correlation between EXCH$\mathrm{Zn}$ and clay content was found in the present work, which explains their high percentages in different fractions of Site 1.

Heavy metals of the soil matrix are complexed over the negatively charged surfaces of colloidal organic matter and clay particles through an electrostatic attraction (Alloway 1990, Adriano 2001). Sungur et al. (2015) determined positive correlations between clay contents and metals of especially less available fractions (OM and RES), indicating that metals were held over negative surfaces of clay particles and between clay layers. Clay adsorption was a dominant process over metal binding into the soil matrix. In our research, $\mathrm{Cu}$ was recovered in $\mathrm{OM}$ and RES fraction in soil samples coming from Site 1, which showed highest percentages of clay $(27.5 \%)$.

\section{Potential availability of trace metals in manure samples}

The distribution of $\mathrm{Cu}, \mathrm{Zn}, \mathrm{Co}$ and Mo fractions obtained by sequential extraction of manure samples coming from IS and ES are shown in table IV. The $\mathrm{Cu}, \mathrm{Zn}$ and $\mathrm{Co}$ distribution among the studied sequential fractions showed a similar behavior. $\mathrm{Cu}$ content in IS samples was similarly distributed in all fractions, observing a predominance of $\mathrm{Cu}-\mathrm{OM}$ (22.7-51.2 $\%)$. Cu-EXCH appeared in higher percentages in IS samples manure than in ES manure and was not detected in soils samples. Zn was highly obtained as RES (48.4-63.8 \%), although Zn-OM and Zn-INOR had also a high recovery percentage with other treatments (Zn-OM: 15.3-25.4 \%; Zn-INOR: 9.0-21.8 $\%)$. Mo showed a similar behavior, being recovered in high percentages as Mo-RES, although major values of Mo-OM and Mo-INORG were detected $(54-21.33 \%)$. The low contents of Co determined in feedlot manure were found mainly as RES fraction (64\%-86.71\%).

Values of $\mathrm{Cu}-\mathrm{OM}$ and $\mathrm{Zn}-\mathrm{OM}$ from IS manure were considerably higher than those found in soil and ES manure (Cu-OM: $13.19 \%$; Zn-OM: $12.66 \%$ ). This can be attributed to the higher total organic carbon content of IS manure and the metal-complexation with organic C-based ligands.
In general, the metal distribution between $\mathrm{EXCH}$, OM and INORG fractions was higher in manure samples from IS compared to ES and soils (Table III). The distribution of trace metals among these fractions varies widely according to the chemical properties of individual metals and the characteristics of manures, which are a function of the animal feed and the manure treatment process (Bolan et al. 2004). L'Herroux et al. (1997) fractionated metals in swine manure and observed that most of $\mathrm{Cu}$ $(66.5 \%)$ was in organic-bound, $\mathrm{Cd}(76.7 \%)$ and Zn (67.2\%) in oxide-bound (call it "weakly bound to specific, mainly inorganic, sites"), and Mn (69.2 $\%$ ) in carbonate-bound forms. The carbonate-bound fraction was mainly related to reducing conditions (i.e., low redox potential) in the manure slurry. Co and $\mathrm{Zn}$ were mainly founded in the "hydroxides" fraction $(75 \%)$. Slurry analysis showed that under reducing conditions and at $\mathrm{pH}$ around 5 , the metals studied in pig slurry were in available forms, except for part of the iron, which remained in the residual fraction.

Sungur et al. (2016) applied a sequential extraction of $\mathrm{Cd}, \mathrm{Co}, \mathrm{Cr}, \mathrm{Cu}, \mathrm{Mn}, \mathrm{Ni}, \mathrm{Pb}$, and $\mathrm{Zn}$ in accordance with the Community Bureau of Reference (BCR) scheme, to manure samples collected from three farms. It is important to emphasize that unlike the sequential extraction procedure employed in our work, the BCR exchangeable fraction, which includes metals adsorbed on essential components such as clays, carbonates and humic acids, is extracted with acetic acid. The reducible fraction includes metals bound to $\mathrm{Fe}$ and $\mathrm{Mn}$ oxides. The oxidizable fraction contains metals that may be complexed or peptised by the natural organic substances. For cow manure samples, these authors detected that Cd (64\%), Mn (52\%), and $\mathrm{Zn} \mathrm{(52 \% )} \mathrm{were} \mathrm{bound} \mathrm{primarily} \mathrm{to}$ acid-soluble and reducible fractions, which were in easily available forms. Likewise, it was also found that $\mathrm{Pb}, \mathrm{Co}, \mathrm{Ni}, \mathrm{Cu}$, and $\mathrm{Cr}$ were in less available fractions (oxidizable and residual [40.92-48.26\% for $\mathrm{Co}, 43.44-45.68 \%$ for $\mathrm{Cu}$, respectively]). In general, this behavior was observed in duck and goat manure. These results are consistent with those obtained from IS cattle manure samples analyzed in our research. For cattle manure, higher percentages of trace metals among acid-soluble, reducible, and oxidizable fractions (considered by the authors as mobile fractions) were obtained. Also, the ability and susceptibility of metals to be released from manure samples is highly related to the extractant employed in the sequential scheme (acidic environment, ion exchange mechanism, etc.). 
Cattle manure from intensive production systems showed a higher value of the exchangeable fraction for all metals in comparison to that from extensive systems and soils. These results suggest a major contribution of labile forms and other available fractions (like bound to organic matter and carbonates) of trace elements to the soil when manure from IS is applied as organic fertilizer. The speciation of trace elements is substantially significant to understand the availability of heavy metals, and the chemical forms content of heavy metals in manure may be traced before being applied in agricultural areas.

Metals introduced to soils undergo several reactions that include adsorption, complexation, precipitation, and reduction, which control their leaching and runoff losses and availability (Bolan et al. 2004). In the case of manure addition, these reactions are evidenced by the presence of a high amount of organic carbon (dissolved organic carbon [DOC]), soluble salt concentration (salinity), and acidification caused by the mineralization of organic nitrogen. Addition of organic amendments such us manure byproducts has shown increases in the organic matter cation exchange capacity in soil. Zhao et al. (2014) observed an increase of the different fractions of $\mathrm{Cu}$ in soils amended with farmyard manure, indicating that organic matter fixed most of the $\mathrm{Cu}$ and the concentration increased with the application of organic matter. Benke et al. (2008) also documented that a portion of the soil EDTA-extractable $\mathrm{Cu}$ reverted to less soluble forms throughout the soil profile related to organic matter retention of metal by complexation.

The addition of DOC promotes the formation of soluble aqueous metal-organic complexes and, to a lesser extent, metal-inorganic complexes, and it is expected to dominate the chemistry of metal solutions in manure-amended soils (Lwin et al. 2018). Such wastes of plant and animal origin contain large amounts of DOC, and the addition of certain organic manures increases the $\mathrm{pH}$ and $\mathrm{EC}$, thereby enhancing the solubilization of soil organic matter (Jackson et al. 1999, Jackson and Miller 2000). EDTA-extractable $\mathrm{Zn}$ significantly increased with long-term manure applications over the years at surface and subsurface depths probably favored the formation of soluble DOC-Zn complexes (Tlustoš et al. 2016). Though organic $\mathrm{Zn}$ was easily decomposed, there was a significant increase in the relative amount of carbon-bound and organic-bound $\mathrm{Zn}$ after manure application. The change of $\mathrm{Zn}$ distribution may be related to the effect of $\mathrm{pH}$ (Illera et al. 2000).

Such increase in DOC may enhance microbial activity, but lowering the reduced redox potential in the soil. Although sthe oluble organic metal fraction is not readily bioavailable to plants, it is relatively mobile, and it has been shown that the application of metal-rich biosolids and animal manure enhances the leaching of metals in soils (Hsu and Lo 2001). The lower $\mathrm{pH}$ and higher OC content due to manure applications may cause increased $\mathrm{Zn}$ solubility and its downward movement (Benke et al. 2008). It is important to emphasize that application of cattle manure as an organic amendment could induce changes in soils properties (such as $\mathrm{pH}$, redox potential organic matter content) and modify the availability and soil fraction distribution of the metals added.

\section{CONCLUSIONS}

It has been found that the exchangeable fraction content of trace elements in manure from intensive beef cattle production systems was higher than that observed in extensive cattle manure and soils. Results indicate that micronutrients, mainly $\mathrm{Cu}$ and $\mathrm{Zn}$, could be easily available in manure samples from intensive production systems. This difference is even more evident in the case of $\mathrm{Cu}$, which was not detected in soils as $\mathrm{Cu}-\mathrm{EXCH}$. The higher levels of total and available forms of $\mathrm{Cu}$ and $\mathrm{Zn}$ determined in IS manure compared to untreated soil samples, indicates that a careful analysis is required when this organic amendment is applied as fertilizer. In any case, the reuse of intensive cattle manure as fertilizer in agricultural areas could reduce the environmental impact of metals accumulation in pen soils and decrease the potential risk of pollution.

\section{ACKNOWLEDGMENTS}

Authors are indebted to Consejo Nacional de Investigaciones Científicas y Técnicas (CONICET) and Facultad de Ciencias Veterinarias, Universidad de Buenos Aires (FVET-UBA) for the financial support in fieldwork.

\section{REFERENCES}

Achiba W.B., Lakhdar A., Gabteni N., Du G., Verloo M., Boeckx P., Cleemput O., Van Jedidi N. and Gallali T. (2010). Accumulation and fractionation of trace metals in a Tunisian calcareous soil amended with farmyard manure and municipal solid waste compost. J. Hazard. Mater. 176 (1-3), 99-108.

DOI: 10.1016/j.jhazmat.2009.11.004 
Adriano D.C. (2001). Trace elements in terrestrial environments. Biogeochemistry, bioavailability and risks of metals. 2nd ed. Springer-Verlag, New York, USA, $867 \mathrm{pp}$.

Alloway B.J. (1990). Heavy metals in soils. 1st ed. Blackie and Sons, Glasgow, UK, 368 pp.

Benke M.B., Indraratne S.P., Hao X., Chang C. and Goh T.B. (2008). Trace element changes in soil after longterm cattle manure applications. J. Environ. Qual. 37 (3), 798-807. DOI: 10.2134/jeq2007.0214

Bolan N.S., Khan M.A., Donaldson J., Adriano D.C. and Matthew C. (2003). Distribution and bioavailability of copper in farm effluent. Sci. Total Environ. 309 (1-3), 225-236. DOI: 10.1016/S0048-9697(03)00052-4

Bolan N., Adriano D. and Mahimairaja S. (2004). Distribution and bioavailability of trace elements in livestock and poultry manure by-products. Crit. Rev. Env. Sci. Tec. 34 (3), 291-338.

DOI: $10.1080 / 10643380490434128$

De Vries J.W., Hoogmoed W.B., Groenestein C.M., Schröder J.J., Sukkel W., De Boer I.J.M. and Groot Koerkamp P.W.G. (2015). Integrated manure management to reduce environmental impact: I. Structured design of strategies. Agr. Syst. 139, 29-37.

DOI: 10.1016/j.agsy.2015.05.010

Eghball B. and Power J. (1994). Beef cattle feedlot manure management. J. Soil Water Conserv. 49 (2), 113-122.

Eghball B. (1999). Liming effects of beef cattle feedlot manure or compost. Commun. Soil Sci. Plant. 30 (1920), 2563-2570.

DOI: $10.1080 / 00103629909370396$

FAO (2002). World agriculture: towards 2015/2030. Summary report. Food And Agriculture Organization of the United Nations [online]. http://www.fao.org/3/ay3557e.pdf 19/12/2014

FAO (2005). Pollution from industrialized livestock production. Livestock policy brief. Livestock information, sector analysis and policy branch animal production and health division. Food and Agriculture Organization of the United Nations [online]. http://www.fao. org/3/a-a0261e.pdf 19/12/2014

Han F.X. and Banin A. (2000). Long-term transformations of cadmium, cobalt, copper, nickel, zinc, vanadium, manganese, and iron in arid-zone soils under saturated condition. Commun. Soil Sci. Plan. 31 (7-8), 943-957. DOI: 10.1080/00103620009370489

Hernández T., Moral R., Pérez-Espinosa A., MorenoCaselles J., Pérez-Murcia M.D. and García C. (2002). Nitrogen mineralisation potential in calcareous soils amended with sewage sludge. Bioresource Technol. 83 (3), 213-219. DOI: 10.1016/S0960-8524(01)00224-3

Hou Y., Bai Z., Lesschen J.P., Staritsky I.G., Sikirica N., Ma L.,Velthof G.L. and Oenema O. (2016). Feed use and nitrogen excretion of livestock in EU-27. Agr. Ecosyst. Environ. 218, 232-244.

DOI: $10.1016 /$ j.agee.2015.11.025

Hsu J.H. and Lo S.L. (2001). Effect of dissolved organic carbon on leaching of copper and zinc from swine manure compost. Environ. Pollut. 114 (1), 119-127. DOI: 10.1016/S0269-7491(00)00198-6

HWAL (1992). Law No 24051, National Decree 831/93. Hazardous Waste Argentine Law. Senado y Cámara de Diputados de la Nación Argentina, Boletín Oficial, January 8, 1992.

Illera V., Walker I., Souza P. and Cala V. (2000). Short-term effects of biosolid and municipal solid waste application on heavy metals distribution in a degraded soil under a semi-arid environment. Sci. Total Environ. 255 (1-3), 29-44. DOI: 10.1016/S0048-9697(00)00444-7

INTA (1988). Cartas de suelos de la República Argentina, Provincia de Buenos Aires. Instituto Nacional de Tecnología Agropecuaria [online]. https://inta.gob. ar/documentos/carta-de-suelos-de-la-provincia-debuenos-aires 13/4/2018

Irshad M., Eneji A.E., Hussain Z. and Ashraf M. (2013). Chemical characterization of fresh and composted livestock manures. J. Soil Sci. Plant Nut. 13 (1), 115-121. DOI: $10.4067 / \mathrm{S} 0718-95162013005000011$

Jackson B.P., Miller W.P., Schumann A.W. and Sumner M.E. (1999). Trace element solubility from land application of fly ash/organic waste mixtures. J. Environ. Qual. 28 (2), 639-647. DOI: $10.2134 /$ jeq1999.00472425002800020030x

Jackson B.P. and Miller W.P. (2000). Soil solution chemistry of a fly ash, poultry litter and sewage sludgeamended soil. J. Environ. Qual. 29 (2), 430-436. DOI: $10.2134 /$ jeq2000.00472425002900020009x

Klemesrud M., Klopfenstein T. and Milton T. (1998). Lime filtrate as a calcium source for finishing cattle. Nebraska beef cattle reports [online]. 347 pp. http:// digitalcommons.unl.edu/animalscinbcr/347/24/1/2018

Krishnamurti G.S.R. and Naidu R. (2002). Solid-solution speciation and phytoavailability of copper and zinc in soils. Environ. Sci. Technol. 36 (12), 2645-2651. DOI: 10.1021/es001601t

Larney F.J., Olson A.F., DeMaere P.R., Handerek B.P. and Tovell B.C. (2008). Nutrient and trace element changes during manure composting at four southern Alberta feedlots. Can. J. Soil Sci. 88 (1), 45-59.

DOI: $10.4141 /$ CJSS07044

Lavado R.S., Zubillaga M.S., Álvarez R. and Taboada M.A. (2004). Baseline levels of potentially toxic elements in pampas soils. Soil Sediment Contam. 13 (5), 329-339. DOI: 10.1080/10588330490500383

Lavado R.S. (2006). Concentration of potentially toxic elements in field crops grown near and far from cities 
of the Pampas (Argentina). J. Environ. Manage. 80 (2), 116-119. DOI: 10.1016/j.jenvman.2005.09.003

L'Herroux L., Le Roux S., Appriou P. and Martínez J. (1997). Behavior of metals following intensive pig slurry applications to a natural field treatment process in Brittany (France). Environ. Pollut. 97 (1-2), 119130. DOI: 10.1016/S0269-7491(97)00072-9

Li Z., McLaren R.G. and Metherel A.K. (2004). The availability of native and applied soil cobalt to ryegrass in relation to soil cobalt and manganese status and other soil properties. New Zeal. J. Agr. Res. 47 (1), 33-43. DOI: $10.1080 / 00288233.2004 .9513568$

Luo X.S, Yu S. and Li X.D. (2012). The mobility, bioavailability and human bioaccessibility of trace metals in urban soils of Hong Kong. Appl. Geochem. 27 (5), 995-1004. DOI: 10.1016/j.apgeochem.2011.07.001

Lwin C.S., Seo B.H., Kim H.U., Owens G. and Kim K.R. (2018). Application of soil amendments to contaminated soils for heavy metal immobilization and improved soil quality-a critical review. Soil Sci. Plant Nut. 64 (2), 156-167.

DOI: $10.1080 / 00380768.2018 .1440938$

Magrí A. and Teira-Esmatges M. R. (2015). Assessment of a composting process for the treatment of beef cattle manure. J. Environ. Sci. Heal. B 50 (6), 430-438.

DOI: $10.1080 / 03601234.2015 .1011942$

MAGyP (2017). Indicadores ganaderos. Anuario 2017. Manual. Ministerio de Agricultura, Ganadería y Pesca, Buenos Aires, Argentina, 16 pp.

Maity S., Sahu S.K. and Pyit G.G. (2017). Trace metals distribution and their dependence on some physicochemical parameters in creek sediment. Toxicol. Environ. Chem. 99 (2), 209-222.

DOI: $10.1080 / 02772248.2016 .1176170$

McGrath S.P. and Cegarra J. (1992). Chemical extractability of heavy metals during and after long-term applications of sewage sludge to soil. Eur. J. Soil Sci. 43 (2), 313-321. DOI: 10.1111/j.1365-2389.1992.tb00139.x

Melgar R. (2006). Uso de micronutrientes en cultivos de gruesa. Proyecto Fertilizar - INTA Pergamino. Reporte Técnico [online]. http://www.fertilizando.com/ articulos $/$ Uso $\% 20 \mathrm{de} \% 20$ Micronutrientes $\% 20$ en $\% 20$ Cultivos\%20de\%20Gruesa.asp 5/12/2018

Miller R.E., Lei X. and Ullrey D.E. (1991). Trace elements in animal nutrition. In: Micronutrients in agriculture (Morvedt J.J., Ed.). Soil Science Society of America, Madison, WI, USA, pp. 593-662.

Miller J.J., Beasley B.W., Drury C.F., Larney F.J., Hao X. and Chanasyk D.S. (2018). Influence of long-term feedlot manure and inorganic fertilizer application on selected metal and trace elements in a clay loam soil. Can. J. Soil Sci. 98 (2), 330-342.

DOI: $10.1139 /$ cjss-2017-0152
Moscuzza C.H. and Fernández-Cirelli A. (2009). Trace elements in confined livestock production systems in the pampean plains of Argentina. World App. Sci. J. 7 (12), 1583-1590.

Nicholson F.A., Chambers B.J., Williams J.R. and Unwin R.J. (1999). Heavy metal contents of livestock feeds and animal manures in England and Wales. Bioresource Technol. 70 (1), 23-31.

DOI: 10.1016/S0960-8524(99)00017-6

Reynolds K., Kruger R., Rethman N. and Truter W. (2002). The production of an artificial soil from sewage sludge and fly-ash and the subseuent evaluation of growth enhancement heavy metal translocation and leaching potential. Proceedings. World Conference on Information Security Applications, Sun City, South Africa. 28th May to 1st June, 2000. Water S. A. 29, 73-77.

Sager M. (2007). Trace and nutrient elements in manure, dung and compost samples in Austria. Soil Biol. Biochem. 39 (6), 1383-1390.

DOI: $10.1016 /$ j.soilbio.2006.12.015

SAGPyA (1995). El deterioro de las tierras en la República Argentina. Alerta amarillo. Secretaría de Agricultura, Ganadería, Pesca y Alimentos y el Consejo Federal Agropecuario. Manual. Buenos Aires, Argentina, $286 \mathrm{pp}$.

Sainz Rozas H., Echeverría H.E., Calviño P.A., Barbieri P.A. and Redolatti M. (2003). Respuesta del trigo al agregado de cinc y cobre en suelos del sudeste bonaerense. Ciencia del Suelo 21 (2), 52-58.

Salazar C. and Moscatelli G. (1989). Soil maps of Buenos Aires province. Instituto Nacional de Tecnología Agropecuaria, Buenos Aires, Argentina, 527 pp.

Sheppard S.C. and Sanipelli B. (2012). Trace elements in feed, manure, and manured soils. J. Environ. Qual. 41 (6), 1846-1856. DOI: 10.2134/jeq2012.0133

Shuman L.M. (1999). Effect of organic waste amendments on zinc adsorption by two soils. Soil Sci. 164 (3), 197-205.

SSS (2014). Keys to soil taxonomy. 12th ed. Soil Survey Staff. United States Department of Agriculture. Natural Resources Conservation Service. Washington, USA, $644 \mathrm{pp}$.

Soriano-Disla J.M., Speir T.W., Gómez I., Clucas L.M., McLaren R.G. and Navarro-Pedreño J. (2010). Evaluation of different extraction methods for the assessment of heavy metal bioavailability in various soils. Water Air Soil Poll. 213 (1-4), 471-483.

DOI: $10.1007 / \mathrm{s} 11270-010-0400-6$

Sparks D. L. (1996). Methods of Soil Analysis: Part 3-Chemical Method. SSSA Book Series, ASA. Madison, Wisconsin, USA, 1309 pp.

Steinfeld H., Gerberm P., Wassenaar T., Castel V., Rosales M. and de Haan C. (2006). Livestock's long shadow - 
environmental issues and options. Food Agric. Organ. United Nations. 3, 1-377.

DOI: $10.1007 / \mathrm{s} 10666-008-9149-3$

Sungur A., Soyla, M., Yilmaz E., Yilma, S. and Ozcan H. (2015). Characterization of heavy metal fractions in agricultural soils by sequential extraction procedure: the relationship between soil properties and heavy metal fractions. Soil Sediment Contam. 24 (1), 1-15. DOI: 10.1080/15320383.2014.907238

Sungur A., Soylak M., Yilmaz S. and Ozcan H. (2016). Heavy metal mobility and potential availability in animal manure: using a sequential extraction procedure. J. Mater. Cycles Waste. 18 (3), 563-572.

DOI: $10.1007 / \mathrm{s} 10163-015-0352-4$

Tlustoš P., Hejcman M., Hůlka M., Patáková M., Kunzová E. and Száková J. (2016). Mobility and plant availability of risk elements in soil after long-term application of farmyard manure. Environ. Sci. Pollut. R. 23 (23), 23561-23572.

DOI: $10.1007 / \mathrm{s} 11356-016-7592-2$
Torri S.I. and Lavado R.S. (2008a). Dynamics of Cd, Cu and $\mathrm{Pb}$ added to soil through different kinds of sewage sludge. Waste Manage. 28 (5), 821-832.

DOI: $10.1016 /$ j.wasman.2007.01.020

Torri S.I. and Lavado R.S. (2008b). Zinc distribution in soils amended with different kinds of sewage sludge. J. Environ. Manage. 88 (4), 1571-1579.

DOI: $10.1016 /$ j.jenvman.2007.07.026

Torri S.I., Urricariet S. and Lavado R.S. (2011). Micronutrient availability in crop soils of the pampas region, Argentina. In: Soil Nutrients (Miransari M., Ed.). Nova Science Publishers, New York, USA, pp. 1-19.

USEPA (1996). Compilation of EPA's sampling and analysis methods. 2nd ed. United State Enviromental Protection Agency-CRC Press, Washington, USA, 1696 pp.

Zhao Y.C., Yan Z.B., Qin J.H. and Xiao Z.W. (2014). Effects of long-term cattle manure application on soil properties and soil heavy metals in corn seed production in Northwest China. Environ. Sci. Pollut. R. 21 (12), 7586-7595. DOI: $10.1007 / \mathrm{s} 113$ k56-014-2671-8 